\title{
Food Habits of Mule Deer in a Semidesert
}

\section{Grass-Shrub Habitat}

\section{HENRY L. SHORT}

Highlight: Mule deer (Odocoileus hemionus) selectively consumed cactus fruit, browse leaves and fruit, and forbs, when present, on semidesert grass-shrub habitats in southern Arizona. Plant species utilized were generally those that have invaded and proliferated on semidesert grasslands during the twentieth century. The seasonal diet seemed deficient in phosphorus, which may affect deer reproduction and general well being.

has developed, in this century, an extensive cover of cactus and perennial woody species (Reynolds and Martin 1968) characteristic of many of the former semidesert grasslands of the

Semidesert grasslands occur on suitable sites at elevations between about 3,000 and 4,500 $\mathrm{ft}$ within the Sonoran Desert. These grasslands have changed drastically in the last century.

During the middle of the nineteenth century, the landscapes were typically open, perennial grasses were plentiful, and mesquite (Prosopis juliflora), although widespread, was not dense. Rivers were marshy, open, and largely unchanneled (Hastings and Turner 1965). Since the turn of the century, cactus and woody perennials of several species have proliferated to produce a less open landscape. These changes are obvious in repeat photographs (Fig. 1). Vegetation changes may have been influenced both by severe overgrazing and by a climatic trend towards increased aridity.

Recent range practices and range research in semidesert grass-shrub habitats have centered on the destruction of cactus and perennial woody species and the reestablishment of perennial grasses. Results of the present food habits study suggest that these range practices would destroy vegetation extensively used by mule deer (Odocoileus hemionus) occupying this vegetation type.

The present study was done on the Santa Rita Experimental Range south of Tucson, Ariz. This research area

The author is principal wildlife biologist, Rocky Mountain Forest and Range Experiment Station, U.S. Department of Agriculture, Forest Service, Fort Collins, Colorado, stationed at Tempe, Arizona.

The author wishes to acknowledge the cooperation of many persons of the Rocky Mountain Forest and Range Exp. Sta. and the Coronado National Forest, U.S. Dep. Agr., Forest Serv., and the Arizona Game and Fish Commission in censusing deer, in collecting stomach samples from hunter-killed and sacrificed deer, and in collecting vegetation samples for in vitro and nutrient analyses.

Manuscript received March 10, 1976
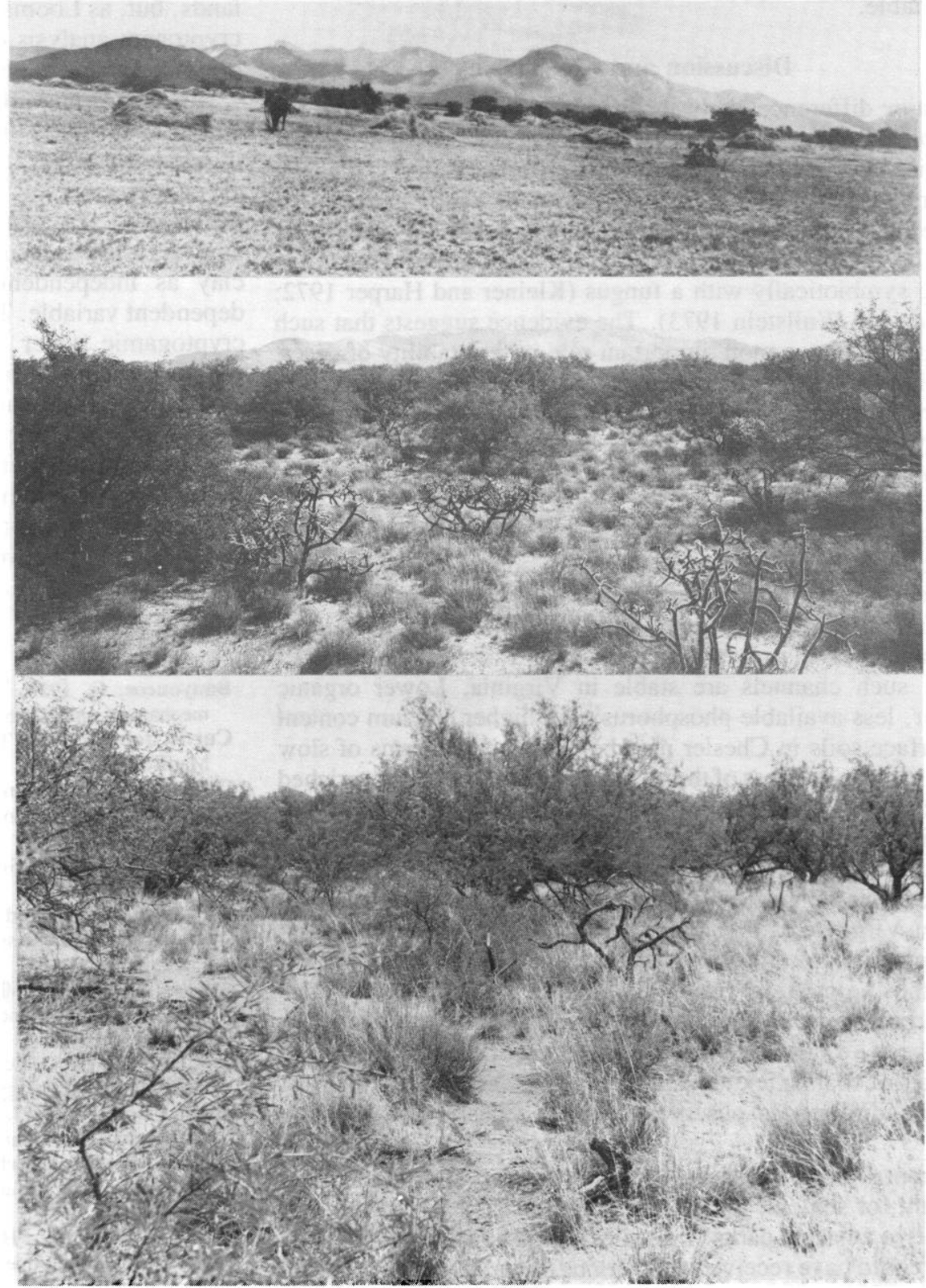

Fig. 1. Repeat photographs from a common photopoint near the center of the Santa Rita Experimental Range. The upper photograph, taken in 1903, pictures the range as desert grasslands. The middle photograph, taken in 1941, shows extensive invasion of woody species onto the range. The lower photograph, taken in 1975, demonstrates the abundant cover presently covering much of the Experimental Range. 
Sonoran Desert region. The perennial vegetation between 3,200 and $3,600 \mathrm{ft}$ is presently dominated by mesquite, burroweed (Aplopappus tenuisectus), and cholla cactus (Opuntia sp.), and above $4,000 \mathrm{ft}$ by mesquite and pricklypear cactus ( $O$. engelmannii). Other shrubs that have become common at upper elevations include catclaw acacia (Acacia greggii), and fairyduster or false mesquite (Calliandra eriophylla) (Reynolds and Martin 1968).

\section{Methods}

Rumen samples were obtained at different seasons from a total of 148 mule deer. Twenty-one were collected during spring (10 in April 1970, one in April 1974, and 10 in May 1971); 20 during summer (4 in August 1973, 12 in September 1971, and 4 in September 1972); 58 during autumn (25 in October 1970, and 33 in November 1969); and 49 during winter (39 in December 1968, and 10 in February 1969). Since deer were collected during different months each year, few differences in food habits or in the nutrient quality of forages could be evaluated between years, even though annual precipitation did vary. Where possible the information obtained from rumen samples was subjected to variance analysis and multiple range tests to suggest differences in food habits between months and seasons of the year.

A 1-quart aliquot of rumen contents was obtained from each deer, and washed to slow fermentation processes and to remove products of fermentation. The remaining particulate matter was stored in quart bottles with $10 \%$ formalin to kill fermentation organisms. The stored materials were later emptied into a flat pan, and the pointframe technique of Chamrad and Box (1964) was used to indicate plant fragments to be identified for analysis. Twohundred contact points were identified for each rumen sample to determine the percent content of each forage species. Scientific names of foods mentioned in the text are listed in Table 1.

Composited samples of available forages were collected from the Santa Rita Experimental Range about 1 week before a seasonal deer collection was made. These vegetation samples were oven dried at $65^{\circ} \mathrm{C}$, milled, and analyzed for crude

Table 1. Plant species (\% of diet) and parts selected by mule deer on the Santa Rita Experimental Range at the four seasons, as determined from the identification of food remnants within the stomach of mule deer.

\begin{tabular}{|c|c|c|c|c|c|}
\hline \multirow[b]{2}{*}{ Species } & & \multicolumn{4}{|c|}{ Season and plant part selected ${ }^{1}$} \\
\hline & & Spring & Summer & Autumn & Winter \\
\hline \multicolumn{6}{|l|}{ Cactus } \\
\hline Jumping cholla & Opuntia fulgida & $19.9 \mathrm{~F}$ & $0.6 \mathrm{~F}$ & $7.7 \mathrm{~F}$ & $2.6 \mathrm{~F}$ \\
\hline Pricklypear & O. engelmannii & $3.2 \mathrm{~F}$ & $10.2 \mathrm{~F}$ & 0 & $0.5 \mathrm{~F}$ \\
\hline Cane cholla & O. spinosior & $1.1 \mathrm{~F}$ & $1.4 \mathrm{~F}$ & $1.2 \mathrm{~F}$ & $10.3 \mathrm{~F}$ \\
\hline Barrel cactus & Ferocactus wislizenii & $5.4 \mathrm{~F}$ & $1.9 \mathrm{~F}$ & $35.6 \mathrm{~F}$ & $42.5 \mathrm{~F}$ \\
\hline Total cactus & & 29.6 & 14.1 & 44.5 & 55.9 \\
\hline \multicolumn{6}{|l|}{ Trees } \\
\hline Mesquite & Prosopis juliflora & $0.3 \mathrm{~L}$ & $24.0 \mathrm{~F}$ & $2.9 \mathrm{~L}$ & $4.9 \mathrm{~L}$ \\
\hline Desert willow & Chilopsis linearis & $4.4 \mathrm{LF}$ & $0.1 \mathrm{~F}$ & $0.5 \mathrm{LF}$ & 0 \\
\hline Total trees & & 4.7 & 24.1 & 3.4 & 4.9 \\
\hline \multicolumn{6}{|l|}{ Shrubs } \\
\hline Catclaw & Acacia greggii & $17.9 \mathrm{~L}$ & $1.9 \mathrm{LF}$ & $11.2 \mathrm{~L}$ & $3.9 \mathrm{~L}$ \\
\hline Fairyduster & Calliandra eriophylla & $9.5 \mathrm{~L}$ & $31.5 \mathrm{~L}$ & $31.1 \mathrm{~L}$ & $21.6 \mathrm{~L}$ \\
\hline Arizona rosewood & Vauquelinia californica & $4.5 \mathrm{~L}$ & 0 & 0 & 0 \\
\hline Ocotillo & Fouquieria splendens & $3.2 \mathrm{f}$ & 0 & 0 & 0 \\
\hline Eriogonum & Eriogonum sp. & $0.7 \mathrm{WP}$ & 0 & 0 & $2.3 \mathrm{WP}$ \\
\hline Thurber anisacanth & Anisacanthus thurberi & $0.5 \mathrm{~L}$ & $0.8 \mathrm{~L}$ & $1.3 \mathrm{~L}$ & $0.1 \mathrm{WP}$ \\
\hline Whitethorn acacia & Acacia constricta & $0.1 \mathrm{~L}$ & $3.1 \mathrm{LF}$ & $2.4 \mathrm{~L}$ & $2.8 \mathrm{~L}$ \\
\hline Kidneywood & Eysenhardtia polystachya & 0 & 0 & $1.3 \mathrm{~L}$ & $0.1 \mathrm{WP}$ \\
\hline Other (4 sp.) & & 1.2 & 0.7 & 0.7 & 0.9 \\
\hline Total shrubs and half-shrubs & & 37.6 & 38.0 & 48.0 & 31.7 \\
\hline \multicolumn{6}{|l|}{ Forbs } \\
\hline Eriastrum & Eriastrum sp. & $9.2 \mathrm{WP}$ & 0 & 0 & T WP \\
\hline Spurge & Euphorbia sp. & $4.8 \mathrm{WP}$ & $16.5 \mathrm{WP}$ & $1.6 \mathrm{WP}$ & 0 \\
\hline Desert marigold & Baileya multiradiata & $2.4 \mathrm{WP}$ & 0 & $\mathrm{~T}^{2} \mathrm{WP}$ & $0.6 \mathrm{WP}$ \\
\hline Tansymustard & Descurainia pinnata & $1.8 \mathrm{WP}$ & 0 & 0 & $0.1 \mathrm{WP}$ \\
\hline Verbena & Verbena & $1.3 \mathrm{WP}$ & 0 & $0.1 \mathrm{WP}$ & 0 \\
\hline Melongourd & Apodanthera undulata & $0.1 \mathrm{~L}$ & $3.2 \mathrm{~F}$ & 0 & 0 \\
\hline Other (33 sp.) & & 3.2 & 2.7 & 0.8 & 3.6 \\
\hline Total forbs & & 22.8 & 22.4 & 2.5 & 4.3 \\
\hline Grasses & & $2.6 \mathrm{WP}$ & $0.4 \mathrm{WP}$ & TWP & $1.0 \mathrm{WP}$ \\
\hline Miscellaneous or unidentified & & 2.7 & 1.0 & 1.6 & 2.2 \\
\hline Grand total & & 100.0 & 100.0 & 100.0 & 100.0 \\
\hline
\end{tabular}

Plant part selected: $F=$ fruit; $L=$ leaves; $f=$ flowers; $W P=$ whole plant.

Eriastrum $\mathrm{sp}$

Verbena

Apodanthera undulata

$2.8 \quad 22.4$

$2.6 \mathrm{WP} \quad 0.4 \mathrm{WP}$

100.0

100.0 protein, calcium, and phosphorus by a commercial laboratory. Additional aliquots from the vegetation samples were subjected to in vitro micro-digestion analyses using the general technique of Tilley and Terry (1963). The rumen inocula used for in vitro analyses were obtained from deer collected on the Santa Rita Experimental Range. The procedure used for determining in vitro digestibility is described by Urness (1973).

The nutrient content of the seasonal diets of mule deer was estimated from the product of the quantity of individual forages in the diet of deer and the nutrient quality and in vitro digestibility of those forages.

The adjectives excellent, good, fair, and poor used to describe the nutrient quality of forages at the different seasons refer to ranges of nutrient values cited by Urness (1973).

\section{Results}

The composition of the diet of deer from the Santa Rita Experimental Range is listed in Table 1. The in vitro dry matter (DM) digestibility and nutrient content of some important items are listed in Table 2.

Spring

April-June is the driest 3-month period of the year on the Santa Rita Experimental Range; moisture is seldom sufficient for plant growth. Foods available to deer during the early portion of this season include cactus fruits remaining from the previous summer, cool-season annuals, and many browse species that begin growth at this time. The rumens of 10 deer collected in early April 1970 contained more barrel cactus fruit $(P<0.05)$ and more forbs $(P<0.10)$ but fewer leaves of catclaw acacia $(P<0.01)$ than did 10 rumens collected in mid-May 1971. Deer apparently utilize the available leaves of browse species heavily when they become available, especially after cactus fruit has been consumed and the cool-season annuals have disappeared.

Fruit of jumping cholla and plant parts of eriastrum were more common $(P<0.05)$ in rumen samples during spring than at other seasons, and leaves of fairyduster were less common $(P<0.05)$. Fairyduster frequently loses its leaves during the spring drought period, but leaves regrow after summer rains begin (Reynolds and Martin 1968). Use of catclaw leaves was greater in spring than during summer and winter $(P<0.05)$, and forbs totaled a greater portion of the diet of mule deer in spring than they 
did in autumn or winter $(P<0.05)$.

During spring, the fruits of jumping cholla and barrel cactus, leaves of mesquite, and plants of eriastrum and spurges are highly digestible $(>50 \%$ of DM). Fruit of pricklypear, leaves of mesquite, catclaw, and fairyduster, and the eriastrum plant have good crude protein levels ( $>10 \%$ of DM). Only the fruit of pricklypear and the spurge and eriastrum plants had good phosphorus contents ( $>0.25 \%$ of DM) and only the fruit of barrel cactus and spurges and eriastrum had $\mathrm{P} / \mathrm{Ca}$ values believed most useful for $\mathrm{P}$ metabolism $(>0.33)$. Estimates of digestibility and nutrient values of plant parts representing $87 \%$ of the identified foodstuffs in the stomachs of the 21 deer killed during the spring are summarized on a composite basis in Table 3 . During spring the composite diet contains plant materials that are highly digestible and of good protein content, but are of only fair phosphorus content and have a high calcium level. The undesirably low $\mathrm{P} / \mathrm{Ca}$ value suggests that phosphorus metabolism might be somewhat inhibited.

\section{Summer}

About half of the annual precipitation on the Santa Rita Experimental Range occurs from July-September. Warm-season annuals, leaf regrowth on shrubs (such as fairyduster), and most perennial grasses develop in response to the summer showers.

During summer, deer feed heavily upon mesquite fruit when it is available. The total precipitation during autumn 1970, winter 1970-71, and spring 1971 was the least recorded on the Santa Rita Experimental Range for any similar 9 -month period in 40 years (Sellers and Hill 1974). Apparently the crop of mesquite fruit following this drought was a failure, for the 12 deer killed during September 1971 had no mesquite fruit in their rumen samples. Mesquite fruit, in contrast, comprised $60 \%$ of the rumen contents of 8 mule deer killed during the summers of 1972-73 following more normal autumn-winter-spring precipitation patterns. During the summer of 1971 , when mesquite fruit was absent from the diet, fairyduster leaves comprised $47 \%$ of the stomach contents of deer. Leaves of fairyduster were significantly less common $(P<0.05)$ in stomach samples during the summers of 197273. There were no significant differences between years in the amount of forbs or cactus fruits in the stomach contents of deer killed during summer.

Fruits of pricklypear and mesquite were consumed at higher rates $(P<0.05)$ during summer, the season of their greatest availability, than at other seasons. Leaves of fairyduster were equally important as deer food in summer, autumn, and winter. More spurges $(P<0.05)$ were consumed during summer than during other seasons, but forbs, as a class, were eaten as readily during summer as in spring.

Leaves of fairyduster were a moderately good protein source, and mesquite fruit and spurges were highly digestible (Table 2). The summer diet of deer, composited from vegetation developed in years following both normal and drought conditions, exhibited good in vitro digestibility, but seemed only fair in protein and phosphorus content and had an undesirably low $\mathrm{P} / \mathrm{Ca}$ value (Table 3 ).

\section{Autumn-Winter}

Rainfall at the Santa Rita Experi- mental Range is low during OctoberNovember and increases from December-March. The cool-season temperatures are not severe and allow an extended growing season. Deciduous species usually lose leaves in late November. Leaves of shrubs develop and cool-season annuals initiate growth in early spring.

Leaves of the deciduous catclaw were of greater importance in autumn than during winter $(P<0.05)$. Leaves of fairyduster were important to deer from October to January but were unavailable in February.

During autumn and winter the fruits of cactus comprised half the diet of deer. The large, easily accessible, yellow fruits of the barrel cactus were selectively consumed. By February, barrel cactus fruit became scarce and the less preferred cane cholla fruits were eaten. Consumption of cane cholla fruits was significantly greater $(P<0.05)$ in winter than during other seasons.

Cactus fruits and some browse leaves were of good to high digestibility during atumn and winter. Protein contents of the autumn leaves of mesquite, catclaw, and fairyduster were good. Phosphorus content, except for the fruit of barrel cactus, was poor for most autumn-winter foods (Table 2). The composite diet of mule deer during both autumn and winter was poor in phosphorus and had poor $\mathrm{P} / \mathrm{Ca}$ ratios during each of these two seasons.

\section{Discussion}

Mule deer on the semidesert grassshrub habitat at the Santa Rita Experimental Range (SRER) consume cactus fruit and the fruit and leaves of perennial woody species. Descriptive studies indicate these plants have, in

Table 2. In vitro dry matter (DM) digestibility and seasonal nutrient content of some foods important to mule deer on the Santa Rita Experimental Range.

\begin{tabular}{|c|c|c|c|c|c|c|c|c|c|c|c|c|c|c|c|c|}
\hline \multirow[b]{2}{*}{ Food item } & \multicolumn{4}{|c|}{ Spring } & \multicolumn{4}{|c|}{ Summer } & \multicolumn{4}{|c|}{ Autumn } & \multicolumn{4}{|c|}{ Winter } \\
\hline & $\begin{array}{c}\text { DM } \\
\text { digest }\end{array}$ & Protein & Phos. & $\mathrm{P} / \mathrm{Ca}$ & $\begin{array}{c}\mathrm{DM} \\
\text { digest }\end{array}$ & Protein & Phos. & $\mathrm{P} / \mathrm{Ca}$ & $\begin{array}{c}\mathrm{DM} \\
\text { digest }\end{array}$ & Protein & Phos. & $\mathrm{P} / \mathrm{Ca}$ & $\begin{array}{c}\mathrm{DM} \\
\text { digest }\end{array}$ & Protein & Phos. & $\mathrm{P} / \mathrm{Ca}$ \\
\hline \multicolumn{17}{|c|}{ Fruits } \\
\hline Jumpng cholla & 59.8 & 2.5 & 0.10 & 0.03 & 61.7 & 10.2 & 0.13 & 0.05 & 48.3 & 8.3 & 0.13 & 0.07 & 43.9 & 5.1 & 0.13 & 0.06 \\
\hline Pricklypear & 41.8 & 12.1 & 0.33 & 0.10 & 44.4 & 5.2 & 0.24 & 0.17 & - & - & - & - & - & - & - & - \\
\hline Cane cholla & 47.0 & 2.7 & 0.09 & 0.02 & 60.0 & 4.6 & 0.11 & 0.03 & 50.6 & 5.3 & 0.14 & 0.05 & 44.2 & 5.0 & 0.09 & 0.02 \\
\hline Barrel cactus & 59.5 & 7.8 & 0.20 & 0.65 & 78.1 & 8.6 & 0.21 & 0.48 & 60.9 & 6.2 & 0.18 & 0.47 & 73.5 & 10.8 & 0.23 & 0.61 \\
\hline \multicolumn{17}{|l|}{ Leaves } \\
\hline Mesquite $^{1}$ & $62.3 \mathrm{~L}$ & $17.6 \mathrm{~L}$ & $0.23 \mathrm{~L}$ & $0.28 \mathrm{~L}$ & $66.5 \mathrm{~F}$ & $9.5 \mathrm{~F}$ & $0.16 \mathrm{~F}$ & $0.23 \mathrm{~F}$ & $44.8 \mathrm{~L}$ & $16.4 \mathrm{~L}$ & $0.10 \mathrm{~L}$ & $0.05 \mathrm{~L}$ & $44.9 \mathrm{~L}$ & $15.8 \mathrm{~L}$ & $0.10 \mathrm{~L}$ & $0.05 \mathrm{~L}$ \\
\hline Catclaw & 43.4 & 13.5 & 0.23 & 0.28 & 30.4 & 16.2 & 0.12 & 0.06 & 34.1 & 17.4 & 0.12 & 0.07 & 23.8 & 8.6 & 0.09 & 0.04 \\
\hline Fairyduster & 35.1 & 10.8 & 0.11 & 0.15 & 28.0 & 10.4 & 0.11 & 0.10 & 30.2 & 12.4 & 0.08 & 0.06 & 33.2 & 9.7 & 0.09 & 0.07 \\
\hline \multicolumn{17}{|c|}{ Whole plant } \\
\hline Euphorbia sp. & 55.9 & 7.8 & 0.36 & 0.36 & 56.1 & 6.5 & 0.15 & 0.13 & - & - & - & - & - & - & - & - \\
\hline Eriastrum sp. & 73.1 & 15.0 & 0.43 & 0.34 & - & - & - & - & - & - & - & - & - & - & - & - \\
\hline
\end{tabular}


Table 3. Nutrient values of the seasonal diets of mule deer on the Santa Rita Experimental Range.

\begin{tabular}{|c|c|c|c|c|c|c|}
\hline \multirow[b]{2}{*}{ Seasons } & \multirow[b]{2}{*}{$\begin{array}{c}\% \text { of diet } \\
\text { accounted for }\end{array}$} & \multirow[b]{2}{*}{$\begin{array}{c}\text { Dry matter } \\
\text { digestibility }\end{array}$} & \multicolumn{3}{|c|}{$\%$ of dry matter } & \multirow[b]{2}{*}{$\begin{array}{l}\mathrm{P} / \mathrm{Ca} \\
\text { ratio }\end{array}$} \\
\hline & & & $\begin{array}{l}\text { Crude } \\
\text { protein }\end{array}$ & Phosphorus & Calcium & \\
\hline Spring & 87.0 & 51.8 & 10.3 & 0.23 & 1.55 & 0.15 \\
\hline Summer & 93.7 & 48.2 & 9.6 & 0.16 & 1.09 & 0.15 \\
\hline Autumn & 93.4 & 45.3 & 10.4 & 0.15 & 1.17 & 0.12 \\
\hline Winter & 91.0 & 53.5 & 9.8 & 0.15 & 1.33 & 0.11 \\
\hline
\end{tabular}

this century, increased in abundance and invaded semidesert grasslands in this region. It seems likely that the mule deer may also have invaded these semidesert grasslands as open areas became less extensive. The combination of increasing amounts of suitable food, cover, stock tanks, and surface irrigation, and the curtailment of unregulated hunting would tend to enhance these former grasslands as habitat for mule deer.

Deer do not eat appreciable amounts of grass (Table 1), but cattle consume foliage and fruit of browse species (Reynolds and Martin 1968). Cattle can therefore be viewed as competing with deer on the SRER. Still, some range improvement practices can favor both deer and cattle. Opening dense stands of mesquite by small patch cuttings can increase perennial grass production, create diversity along the edge of the openings, and still leave cover and browse on the uncut areas. The extensive destruction of cactus, mesquite, and other perennial woody species to improve range for livestock or for urban development, however, would destroy this mule deer habitat. Severe drought, a periodic occurrence in the arid Southwest, will also adversely affect deer by reducing the abundance of major food items.
Animals frequently sample vegetation more selectively than does man. Mule deer on the SRER may be able to select vegetation of somewhat higher quality than that listed in Table 2 . Cactus fruits, however, are eaten in their entirety and it is difficult not to sample them correctly for nutrient content and in vitro digestibility. The abundance of cactus fruits in the diet of deer suggests that the nutrient analyses in Table 2 do reflect the relative quality of the diet of these deer.

Cactaceae are a conspicuous vegetation form at the SRER even though they cover less than $4 \%$ of the surface area. Total surface area covered by pricklypear was $2.4 \%$, by cane cholla $0.9 \%$, by jumping cholla $0.5 \%$, and by barrel cactus only $0.04 \%$. Deer at each of the seasons obviously sought the fruit of cactus out of proportion to its abundance in the environment, even though many cactus fruits have low protein and phosphorus contents (Table 2).

The nutrient analyses used in developing Table 3 indicate that-except for the fruit of pricklypear and barrel cactus, browse leaves during spring, and growing forbs-most food items had less than $0.16 \%$ phosphorus and a relatively high calcium content. The estimate of phosphorus intake as a percent of dry matter and the phosphorus/calcium ratios in the composite seasonal samples suggest that mule deer were feeding on range vegetation generally deficient in phosphorus. Phosphorus deficiencies can affect growth, general well being, and reproduction in ruminants (Church 1971). One cannot determine the condition of animals on the basis of their stomach contents, but it is interesting to note that the 12 mature does collected during April and May in this study contained only 15 fetuses, a modest reproduction rate. Such limited doe: fawn ratios in utero suggest low recruitment rates, which is a consideration to be weighed in developing harvest management options.

\section{Literature Cited}

Chamrad, A. D., and T. W. Box. 1964. A point frame for sampling rumen contents. J. Wildl. Manage. 28:473-477.

Church, D. C. 1971. Chapter 19-The macro (major) minerals. p. 417-472. In: Digestive physiology and nutrition of ruminants. Vol. II-Nutrition. Oregon State Univ. Book Stores,Inc., Corvallis.

Hastings, J. R., and R. M. Turner. 1965. The changing mile. Univ. of Arizona Press, Tucson. $317 \mathrm{p}$

Reynolds, H. G., and S. C. Martin. 1968. Managing grass-shrub cattle ranges in the Southwest. U.S. Dep. Agr., Agr. Handb. 162. $44 \mathrm{p}$.

Sellers, W. D., and R. H. Hill. 1974. Arizona climate 1931-1972. Univ. of Arizona Press, Tucson. $616 \mathrm{p}$.

Tilley, J. M. A., and R. A. Terry. 1963. A twostage technique for the in vitro digestion of forage crops. J. Br. Grassl. Soc. 18(2): 104-111.

Urness, P. J. 1973. Chemical analyses and in vitro digestibility of seasonal deer forages, Part II. In: Deer nutrition in Arizona chaparral and desert habitats. Arizona Game and Fish Dep. Spec. Rep. 3. 68 p.

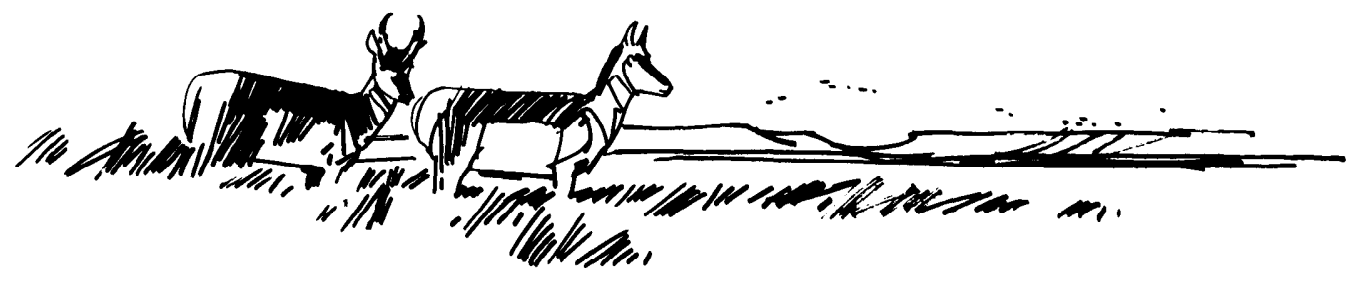

